\title{
The Rider on the White Horse
}

\section{Georgiana Goddard King}

To cite this article: Georgiana Goddard King (1922) The Rider on the White Horse, The Art Bulletin, 5:1, 3-9, DOI: 10.1080/00043079.1922.11409721

To link to this article: http://dx.doi.org/10.1080/00043079.1922.11409721

\section{Published online: 22 Dec 2015.}

Submit your article to this journal 준

LII Article views: 1

Q View related articles $\sqsubset$ 


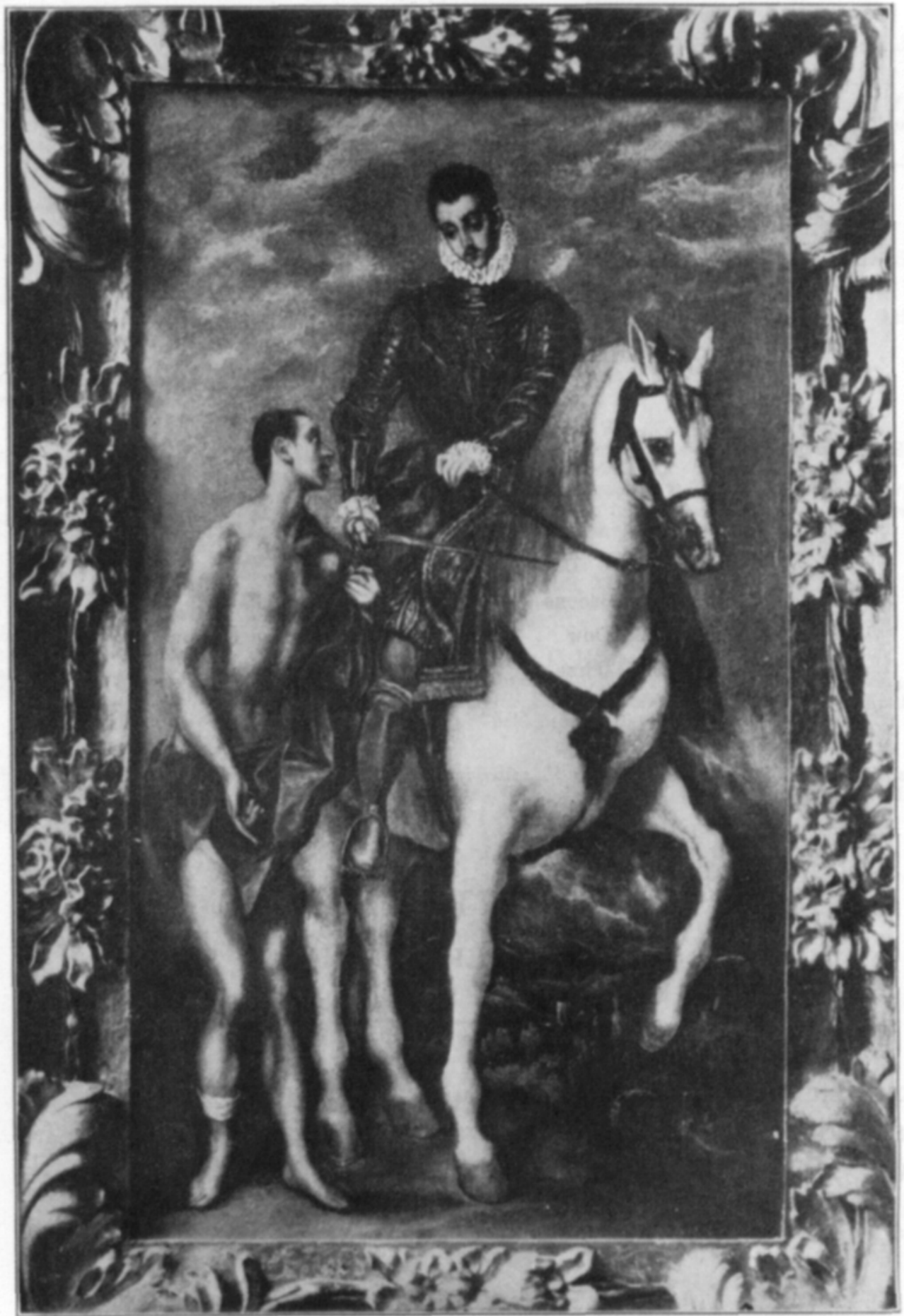

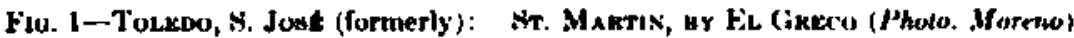




\title{
The Rider on the White Horse
}

\author{
By Georginna Goddard King
}

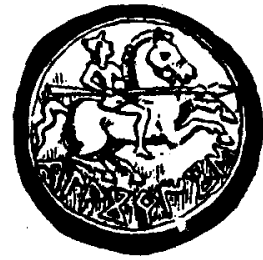

$\mathrm{N}$ a relief from the tomb of the Blessed Albert of Pontida (Fig. 2) which Professor Arthur Kingsley Porter ${ }^{1}$ found in the sacristy of San Giacomo, Albert's old Cluniac priory, at Pontida, near Bergamo, ${ }^{2}$ occurs a significant subject, the identification of which is the starting point of this study in iconography. The relief represents St. James Major as the lord of the dead, a rare aspect of his cult except upon the pilgrimage-road to Compostella. Iconographically it is, so far as $I$ know, unique. He is the rider on the white horse of the Fourth Miracle (dated 1080, but written c. 1130), who carried the living and the dead. Professor Porter wished to date the relief shortly after 1095: I am not quite sure for my part that it should not be put later, at any rate after the death of another Piedmontese saint, the Blessed Albert of Vercelli, who had been on the pilgrimage to St. James, who died in the Holy Land in 1214, and who came to be associated with Elijah and the Carmelite order and revered even by Mohammedans. The reason for this later approximation will presently appear. Professor Porter very justly notes the parallel between the relief and the third horseman of the Apocalypse, who is painted only in a Spanish series of manuscripts that range from the eighth to the eleventh century or later and exist at Urgell, Madrid, Paris, and elsewhere, and are transcriptions of the Commentary of a Spanish monk Beato of Liebena. The relief belongs absolutely to the Compostellan eycle and is a plastic parallel to The Vision of Thurkill," in which the souls were weighed in the Basilica of the Apostle by St. Michael. Here St. James recombines the two aspects of Horus which were usually split and divided between himself and St. Michael. The three naked souls waiting in a palm tree are the souls expectant in the Paradise of God; on the northernmost door of the Portico de la Gloria of Master Matthew they sit in rich leafage. Further, they are equivalent to those souls unborn who sit in trees and sing, and the tree is the date palm in which Carpaccio set his St. Ursula with a row of cherubheads for the cluster of fruit. This part of the relief seems to be derived directly from sculpture on a capital. The theme belongs," as said, to the pilgrimage- "MIGRAVIT AD ASTRA," says the epitaph-and goes back ultimately perhaps to Egypt, with which the Spanish connection was always close. The priory of San Giacomo was burned in 1373 and the relics translated to S. Maria Maggiore in Bergamo: but the horseman went too. He rides between two bishops, high in the north porch. Indeed, he stayed permanently on North Italian sepulchral monuments, like that of Bernabo Visconti in Milan and those of the Scaligers in Verona.

'Whom I must thank for the generous loan of photographs for reproduction.

2A. K. Porter, Lombard Architecture, vol. I, passim; vol. III, pp. 294 ff.; plate 189, fig. 2.

" And when he had opened the third seal, I heard the third beast say, Come and see. And I beheld, and, lo, a black horse; and he that sat on him had a pair of balances in his hand." (Rev., vi, 5.)

The Vision of Thurkill, published by H. L. D. Ward, Journal of the British Archoological Association, vol. XXXI (1875), pp. 420-459.

'The Egyptian Liturgy of the Holy Apostles says: "Before the resplendent throne of Thy majesty, O Lord, and the exalted throne of Thy glory, and on the awful seat of the strength of Thy love and the propitiatory altar which Thy will hath established, in the region of Thy pasture, with thousands of cherubim praising Thee, and ten thousands of seraphim sanctifying Thee, we draw near, adore, thank, and glorify Thee always, O Lord of all." It is common also in the Odes of Solomon, which Dr. Rendell Harris inclines to think are Antiochene. 
The investigation of the iconography in question has various aspects.

First, there is St. James as lord of the dead. This I have followed out in my book, The Way of St. James, and must assume as demonstrated: he leads the souls; he, or St. Michael, his surrogate, weighs them in judgment. At Compostella on the south façade he stands between two cypress trees in this cult-aspect, as a chthonian power (Fig. 3). The church was begun in 1078 and consecrated in 1102. Aymery Picaud saw the cypress trees in 1120 and mentioned them about 1130. This cult-image was copied on the transept-face at Toulouse (Fig. 4), and the cypress trees prove the priority of Santiago to St. Sernin.

Secondly, there is the figure of the horseman, developing with St. James as rider; this also must be taken as demonstrated in The Way of St. James.

The original Iberian horseman of the coins (see the initial of this article, an Iberian Jinete on a Roman coin of Jelsa) and the Salas relief, Mélida ${ }^{1}$ believes to be one of the Dioscuri, namely, Castor, the mortal twin:

The so-called Thracian horseman of the Imperial Ottoman Museum (Fig. 5) was doubtless, on the cult side, such another as Castor, a tribal hero, honored after death. The sculpture, brought from Salonica about 1874, was said to have been found "on the portico of Constantine" - an odd and early association of rider and emperor, completely accidental, as the Arch of Galerius was probably intended. Another report will have it embedded in the city walls. The museum catalogue would like to make the piece a funerary monument, but admits that the figure may well be "un Héros propylaos." The two attendant barbarians are Hellenistic, Pergamene in style; the work is hard to date, but cannot be very far from the Christian era. ${ }^{2}$ This rider constitutes the earliest fully developed example that $I$ have found of the theme, but plastically this figure, it is easy to see, had predecessors. It shows already the elements that are to appear later: comparing it with the Defender of the Faith, we find the rearing horse, the flying cloak, the form under the horse's belly, the attendants behind; and certainly the missing plaque of the Barberini Ivory held another vertical figure at the right: comparing it with the Verona Theodoric, we find the cloak, the dog, and the vertical motive on the extreme right: comparing it with almost any presentation of St. George, we find the same themes of dragon-killer, rearing horse, raised lance, and animal underneath.

St. James as rider is found in Romanesque sculpture of the twelfth century, for instance, inside the south transept at Compostella (Fig. 6), and in Gothic sculpture, for instance at Betanzos and La Coruña (Fig. 7), and thenceforward, as Santiago Matamoros.

We have particularly to deal with the rider on the white horse. "The most perfect plastic presentation of it is on the Barberini ivory, the figure whom some have called Constantine and some have called Justinian: he is, like that of the Pontida sculpture, a figure of folk-belief, a tribal hero, manifested for the moment as an emperor. But even more interesting is the Louvre relief of Horus slaying the crocodile.

In Egypt Horus was a tribal hero-belonging to those Egyptians whose totem was the sparrow hawk. He is also a sort of twin, for there are two of him, one an elder son, the other born of the dead Osiris. Finally, he is a rider: Plutarch knew that, and had great trouble in explaining it when discussing the mysteries of Osiris. That these mysteries touch folk-belief and primitive currents of thought, I need not stop to show: let me

'J. Ramón Mélida, El Jinete Ibérico, Bol. Soc. Esp. Exc., vol. VIII (1900), p. 175.

${ }^{2}$ Gustave Mendel, Catalogue des Sculptures, Constantinople, 1914; vol. II, pp. 172-175.

8"And I saw, and behold a white horse, and he that sat on him had a bow, and a crown was given unto him, and he went forth conquering and to conquer." (Rev., vi, 2.) 
Phate It

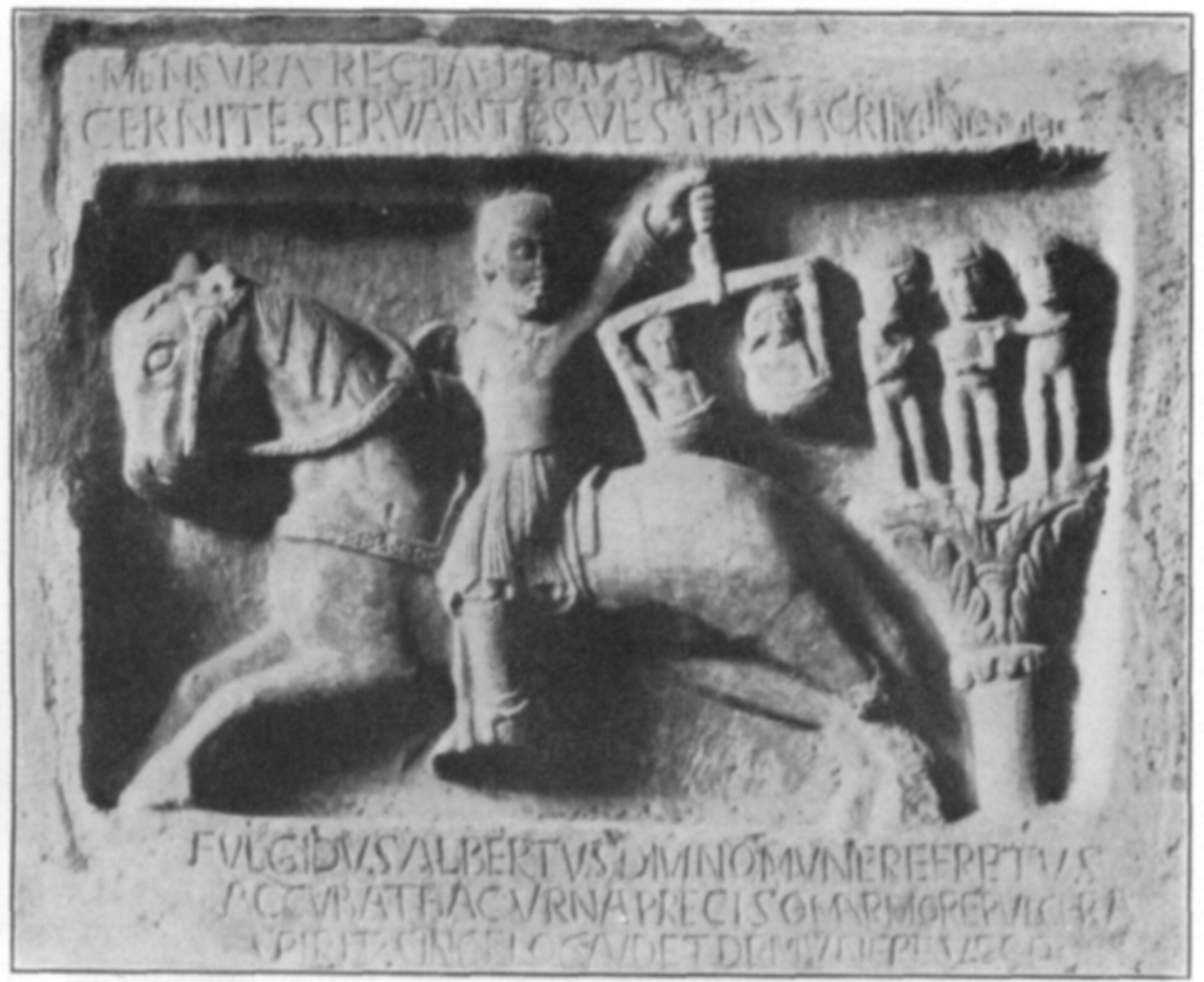

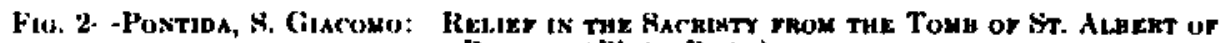
Pontioa (Pholo. Porlet)

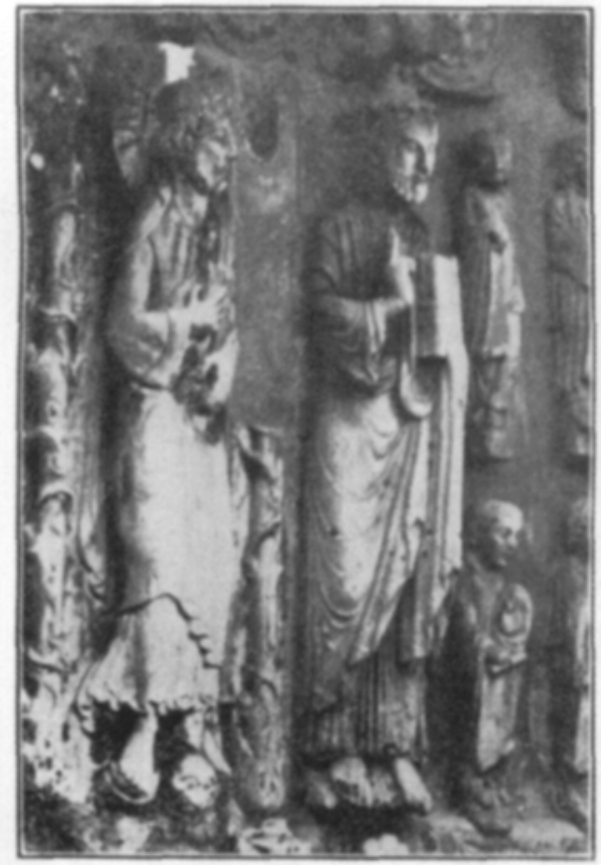

Flo. j-gantiatio dy Componthlla,

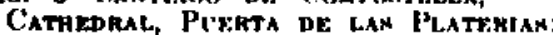
BiT. JAMVM HETWEEN (YPHEN THEEN (Photo. Porter)

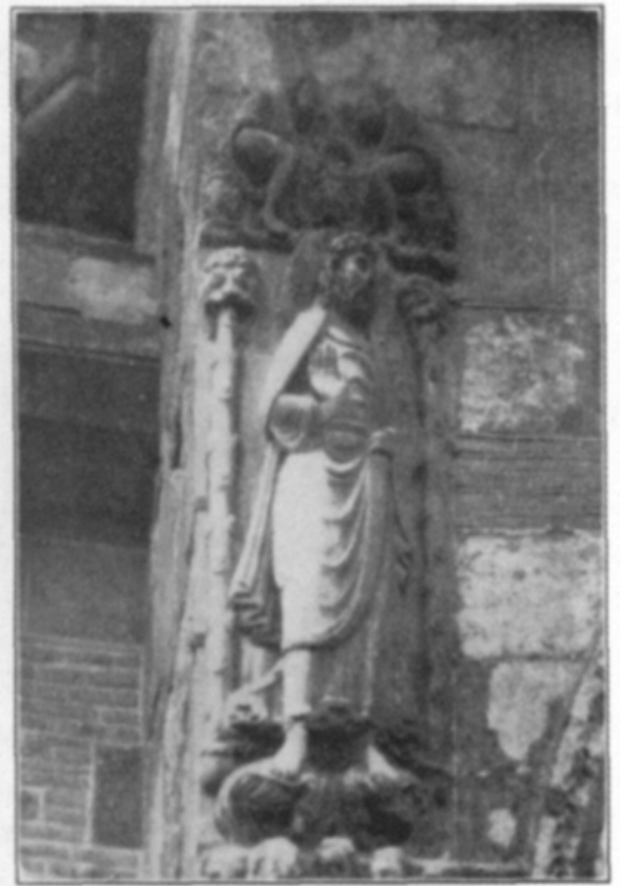

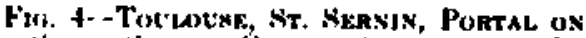

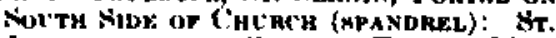
Janes betwies Cypreses Trees (Photo Porter) 
Phate in

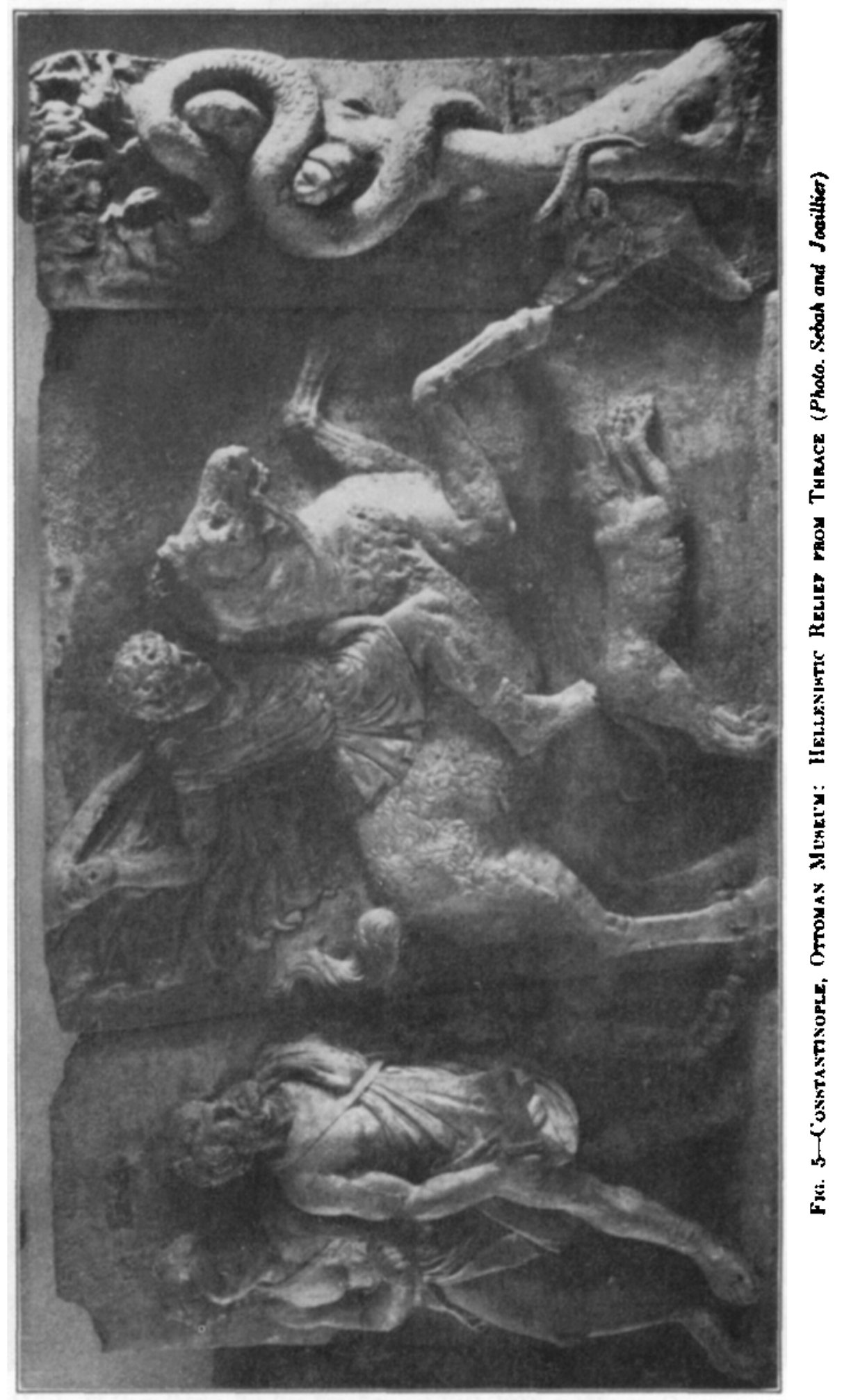


Plate iv
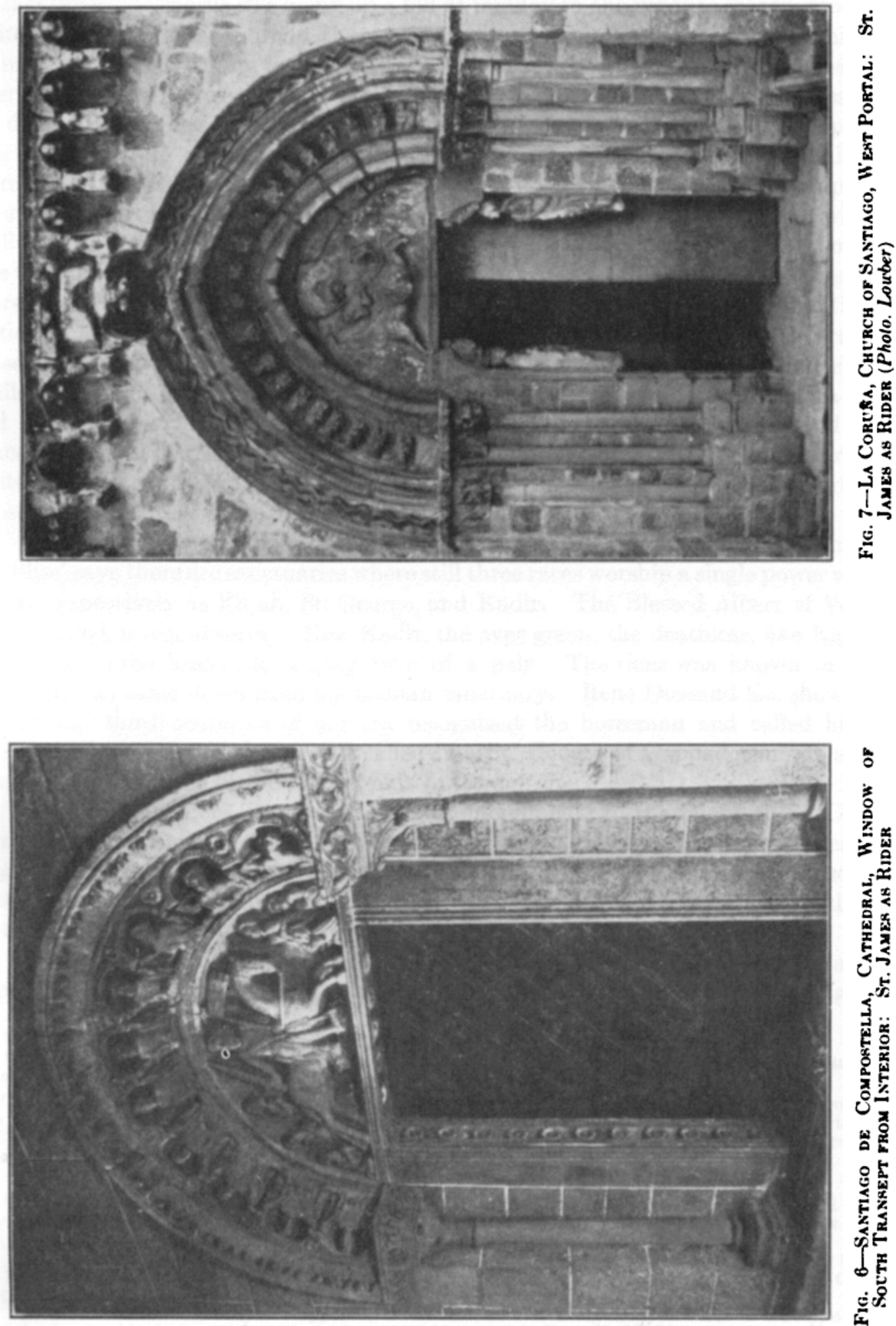
instead cite (from a demotic papyrus of the third century, A. D.) the opening of a spell against fever:" "Horus was going up a hill at midday in the verdure season, mounted on a white horse." He came upon the gods sitting at table, and they invited him to join them; he declined, saying he had had a touch of fever. Then the charm goes on. The rider survives in Egypt through all changes of religion: as St. Apollo he is carved over the door of a mosque at Dashlug, ${ }^{2}$ he is on a comb found at Antinoë and on a Coptic mirror. The famous figure of Christ now in Berlin is not, however, this rider but his mystical correlative, the despised and rejected, the king who comes meek and riding upon an ass. There is a tradition among Arabs, in Syria, and apparently among Copts, that when Christ shall come to fight with Antichrist, in the field of Armageddon, he will be riding on an ass. The Coptic churches of Egypt are full of horsemen saints-Sts. Demetrius, George, Sergius, Mercurius, ${ }^{3}$ for instance, as in the reliefs at Abu Sargh attributed to the eighth century. Butler gives the pictures of two horsemen undated but traditional, which are very like those two icons of the two Sts. Theodore that anyone may see in Greek churches today, or like the Sardinian soldier saints, at the two ends of the predella, at Ardara and Olani and in many a little island sanctuary. I might add that the second book of Maccabees, which relates the expulsion of Heliodorus from the temple by a rider on a white horse, is connected somehow with Egypt. The rider in this case is escorted by the Dioscuri, but himself can be only Jahweh, the tribal god.

This brings us to Syrian soil, where Jewish, Christian, and Arab lore intermingle. Dr. Bliss ${ }^{6}$ says there are sanctuaries where still three races worship a single power whom they invoke respectively as Elijah, St. George, and Kadir. The Blessed Albert of Vercelli was also included, it would seem. Now Kadir, the ever green, the deathless, like Elijah, seems in some sense the heaven-mounting twin of a pair. The rider was known in Syria ever since Mithras came down from his Iranian sanctuary. René Dussaud has shown how the second and third centuries of our era recognized the horseman and called him Apollo. The Crusaders recognized him and called him St. George of Cappadocia. It seems that at a certain point one of the twins tends to disappear.

In Antioch, where Tiberius had set up monuments to the Dioscuri, St. George was seen fighting for the Crusaders in 1098. The Normans claimed that he fought earlier with Roger's soldiers in Sicily, at Cerami, in 1087. He picked up an Aragonese soldier in a battle in Palestine and carried him to the fighting where King Peter was at the siege of Huesca, in 1095.

Now the early church knew St. George only as a much martyred man, and in 494 Pope Gelasius issued a formal warning against his legend. Notwithstanding, his cult

${ }^{1}$ M. A. Murray, Ancient Egyptian Legends, p. 112.

2J. Strzygowski, Ursprung der Christlichen Kirchenkunst, pp. 148-150; figs. 54, 60. Cf. O. M. Dalton, Byzantine Art and Archoology, p. 211, note 2.

${ }^{3}$ May I point out that St. Mercurius must by his name be equated with Hermes, who is Psychopompos, and so with Horus; that St. Sergius is ordinarily coupled with St. Bacchus and falls into the category of twins; and that St. Demetrius is a warrior saint, who turns up with St. Martin at Beauvais and in the Greek legend cures, like the Dioscuri, by incubation?

${ }^{4}$ The Ancient Coptic Churches of Egypt, Vol. II, Frontispiece.

s"Now as he was there present himself with his guard about the treasury, the Lord of spirits, and the Prince of all power, caused a great apparition, so that all that presumed to come in with him were astonished at the power of God, and fainted, and were sore afraid.

"For there appeared unto them an horse with a terrible rider upon him, and adorned with a very fair covering, and he ran fiercely, and smote at Heliodorus with his forefeet, and it seemed that he that sat upon the horse had complete harness of gold.

"Moreover two other young men appeared before him, notable in strength, excellent in beauty, and comely in apparel, who stood by him on either side, and scourged him continually, and gave him many sore stripes.

"And Heliodorus fell suddenly unto the ground, and was compassed with great darkness: but they that were with him took him up, and put him into a litter." (II Maccabees, iii, 24-27.)

'F. J. Bliss, The Religions of Modern Syria and Palestine, p. 10. 
brought home perhaps by the first Crusaders, flared up like a beacon in all the great seaports: the Slavonians, the Venetians, the Genoese, the Barcelonese (Cf. Fig. 10) acclaimed him, and probably Bordeaux, on the Atlantic. At Ferrara, over the cathedral door, he rides precisely like St. James; and the patrons of the Order of Santiago and of the Order of the Garter are interchangeable.

The Dioscuri, whose cult was established at Sparta, did not come from the north but were tribal heroes, "and this rider, who so often appears as one of them, is roughly speaking a Mediterranean power: Cappadocia, Syria, Egypt, Sardinia (which claims the dragon-slaying of St. George and shows the field reddened with the blood of virgins sacrificed) and the Balearic Isles, Venice, Genoa, Catalonia, and the Iberian land even to Compostella and the cape of Finisterre-this itinerary defines and limits the original habitat of the figure, if you but add from Danubian lands what is variously called Hungary, Pannonia, and Slavonia. For in Bamberg the figure of the rider is known as St. Stephen of Hungary; and St. Martin came from Pannonia to Gaul, and was a soldier before he was a bishop.

Now I can state the postulate which our investigation confirms.

We all know the syncretic tendency of cults, and it is possible the rider is a separate and more primitive power than the twins, with whom he tends to coalesce. Certainly he is not, at any time when he is found exercising a real power, an allegory. He is a dim pictorial image in men's minds; he may be called Horus or Constantine or Kadir; he may be worshipped under a thousand different names. There are other such images, for example, the tree full of souls which is found in the Irish Voyages and on the organ-doors of the Museo Correr, carved in this relief at Pontida, and seen on Hampstead Heath by William Blake. Where these images come from, I cannot say; we may ultimately have to learn that from the anthropologist or from the psychoanalyst. But in the study of art we have to recognize their existence, and by our knowledge of children's images, and perhaps of animal psychology, make out a little how the vague and floating form persists not only in the imagination of individuals but in the memory of a people.

The essentials are two, in this case- he rides, and he is a tribal hero. The Sassanian relief, ${ }^{2}$ rock-cut, can tell us no more than that: the great king may be an ancestor, or may be a god, but he is the Persians' own and he is a horseman. Strangely enough he is not found in the purely Latin or the purely Tuscan land. He is rare in Italy-in sculpture very rare, in painting uncommon. Simone left out the horse when he painted the life of St. Martin. But Paul the Deacon found a Lombard legend of a rider at Spoleto. At Castel del Monte Frederic II brought workmen from Cyprus; at Lucca there are Lombard names among the founders and eastern elements in the architecture; and at Castel del Monte the rider occurs over a doorway of the court, and at Lucca on the façade of $S$. Martino, signed in the middle of the thirteenth century (Fig. 8).

St. Martin affords an instance, not unique, of commercialism in hagiography. The soldier saint from Hungary was choked off, superseded, by the bishop, in the interest of the rich abbey at Tours. The traces of his earlier cult are not hard to follow. The figure of the young knight who shares his cloak is the typical one everywhere out of range of Marmoutier and Tours: at Valencia (Fig. 11), at Naples (Fig. 9), at Estella.

There is some reason to believe he led the Normans at the battle of Hastings, as St. George led them at Cerami: there was a rider on a white horse, with hauberk over his

'Farnell, Hero Cults and Ideas of Immortality, p. 191.

${ }^{2}$ M. Dieulafoy, L'art antique de la Perse, vol. III, plate ii. 


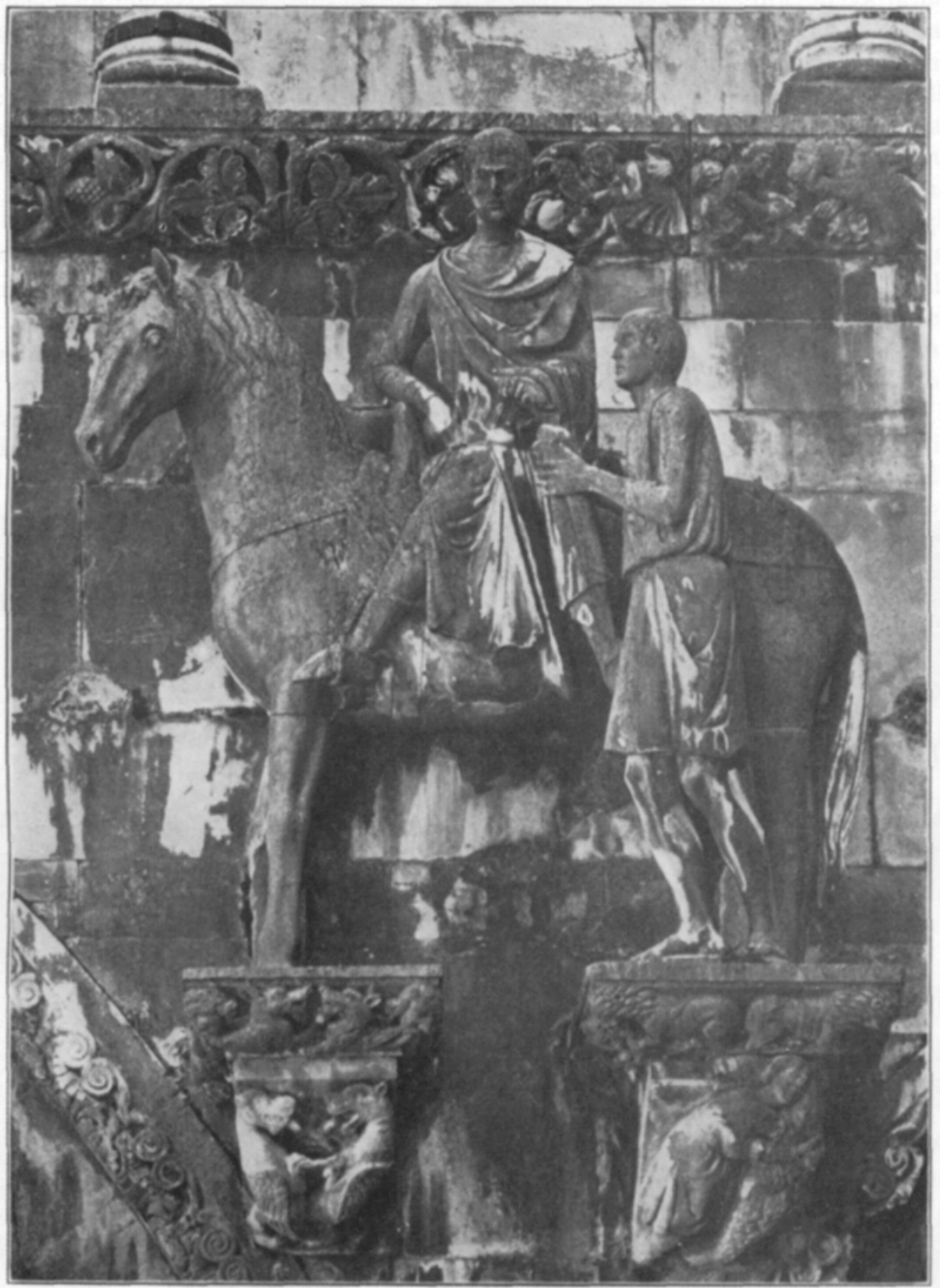

Fim, 8-lecca, Cathedpal, Fagade： St. Martin 


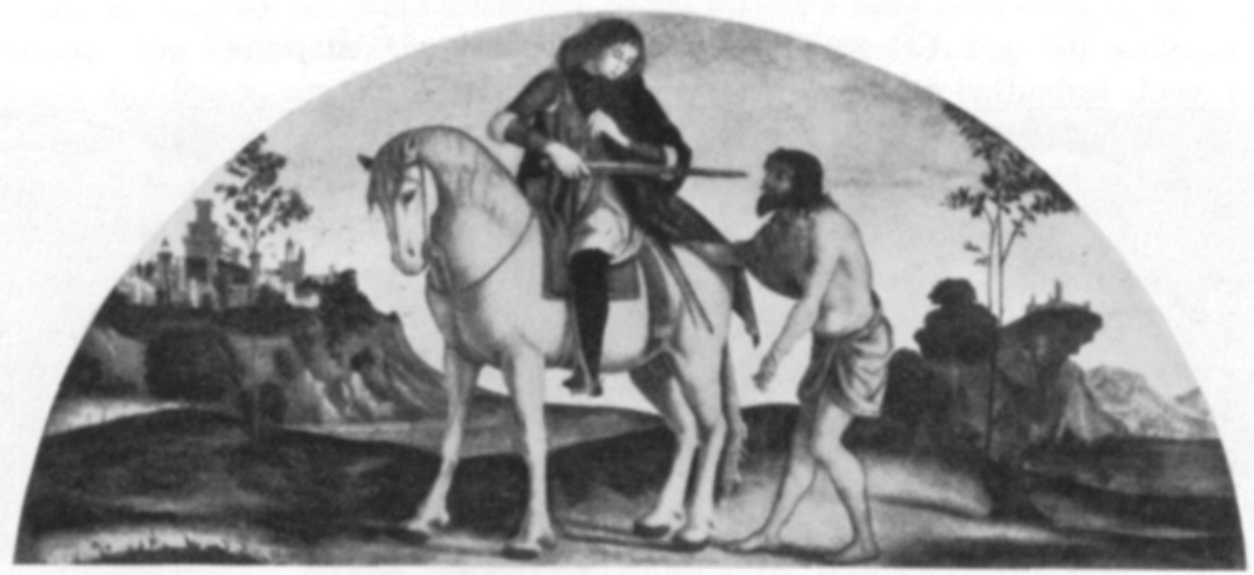

Fig. 9--Nazlem, Muneo Nazton ale: St. Martin (Photo. Alinari)

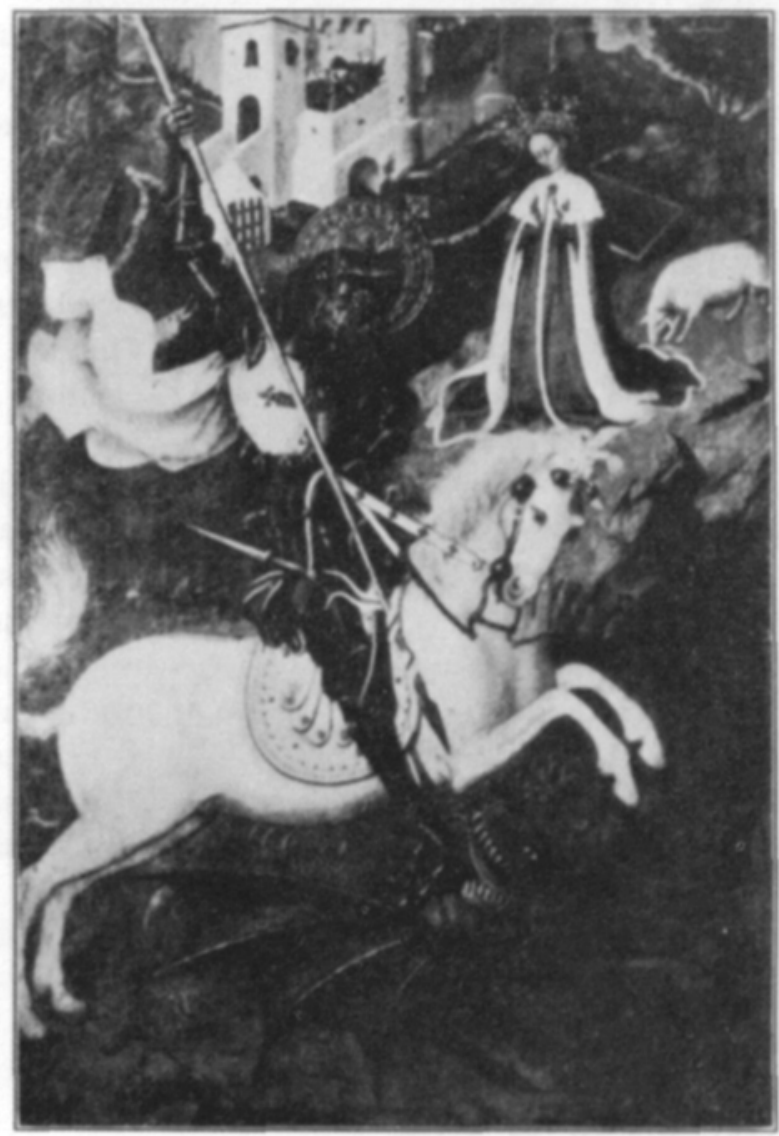

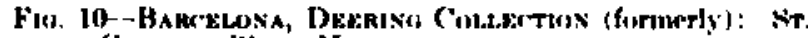
Grortix (Photo. Mat)

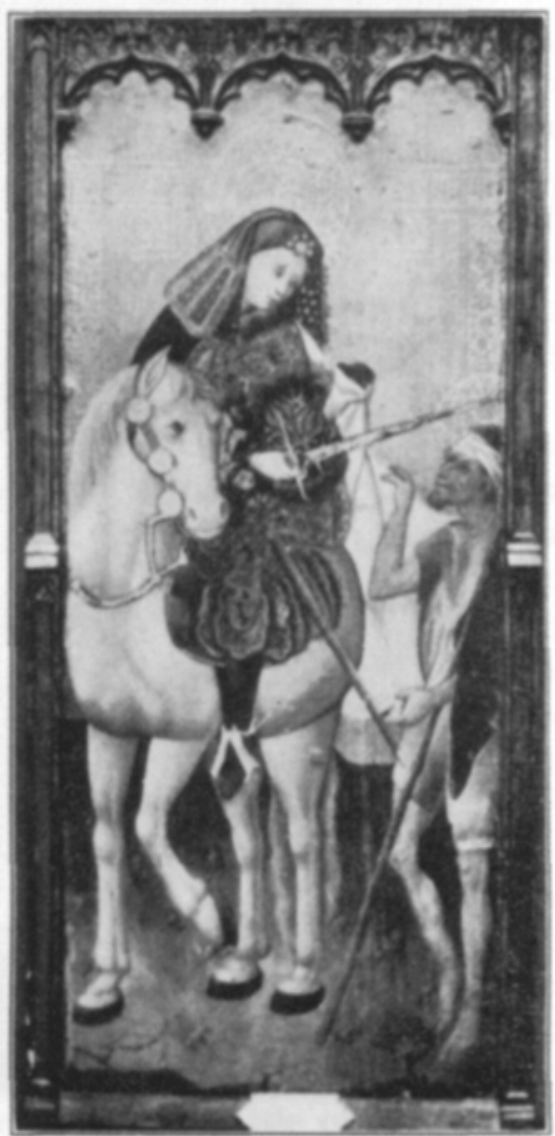

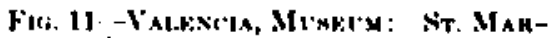
TIN (l'hoto. firolls) 
alb, precisely as Gonzalo de Berceo describes Santiago and St. Millan as appearing at the battle of Simancas. To be sure Wace says it was Bishop Odo of Bayeux-but Wace has no stomach for marvels, and in his legend of St. George allows neither dragon nor princess. He uses the same method that Bernal Diaz uses to get rid of the apparitions of St. James in the Americas.' And why should the horse be white, when even William's own horse fetched from Spain by a pilgrim returning from Compostella has no stated color? William the Conqueror dedicated Battle Abbey to "St. Martin the patron of the soldiers of Gaul." It was named the Monastery of St. Martin of Battle. Duke William's father, Robert the Devil, on his way to the Holy Land passed through Rome, saw and recognized a horseman, and gave him a cloak from his own wardrobe. He blamed the barons of Rome for neglecting so their advocate. Wace calls this figure Constantine, after the manner of the twelfth century-but Wace is writing a hundred and fifty years after the event. He is clear about the gift, for his grandfather Tosteins was the duke's chamberlain and picked out the cloak no doubt. Constantine was a patron, never an intercessor, and there is no sense in the cloak episode unless the rider were St. Martin. There is one other cloak episode that I recall, and no more. Polyeuctes, who is also a soldier saint, had a vision of Christ, who took from him his torn and worn chlamys and replaced it by a new chlamys of silk with a gold buckle and gave him a winged horse on which he is to ride to heaven - the resultant figure being neither more nor less than the Dashlug relief. We forget sometimes how the twelfth century euhemerized and adapted-it may seem very primitive to us, but it was really an extraordinarily complex and sophisticated age, which was putting its own interpretation on an altered past. The later Middle Ages did call the riders on French churches Constantine, and Wace relates according to his lights.

In the thirteenth-century Beauvais window, though it was composed in the interest of the great abbey, and he is ordained deacon before he sees Christ, St. Martin rides three times, at least, and is coupled with St. Demetrius, and the heavenly twins appear to him, "two angels casqued and armed," forming such a conjunction as in the miracle of Heliodorus driven from the temple. The figure at Saint-Étienne-le-Vieux of Caen is certainly St. Martin: my notebook is positive. On the doors of churches dedicated to St. Martin horseshoes were nailed up, by a primitive use, that apparently still persists, at Amiens and at Palada in the Pyrenees alike. I am certain that I have seen St. Martin as rider figuring in Spanish churches, for example, at Irache on a capital, with the more conviction because Spain boasts an early St. Martin of her own, him of Braga, called also Dumiensis, who came likewise from Pannonia to convert the heathen in the West, and died a bishop, being born in 520 and dying in 580, and his day being kept on March 20 .

The horseman, whether St. Martin or Santiago, is a fairly common figure on Spanish Romanesque churches, at Puente la Reyne, for instance, at St. Mary Roadside of Carrion, at S. Andrés of Armentia, and elsewhere; as a rule, and in the earlier work, the pendant to it is a man dominating a lion. The significance of this I do not fully understand and it is not necessary here to explain. There is also a figure of St. Martin at Angoulême, pendant there to St. George.

Of the horsemen that are found on churches in the west of France I have left myself too little space to speak and mere indication must suffice. They all appear shortly after that outbreak of apparitions in battle, 1087, 1095, 1098.

C. Enlart says there are twenty-five known and recorded; he opines that they represent Constantine and where there is a second, then Charlemagne. E. Mâle has made

'G. G. King, Military Orders in Spain, p. 191.

${ }^{2}$ Rendell Harris, The Dioscuri in Christian Legend, pp. 58-59. 
accessible to all ${ }^{1}$ the cases where the twelfth and sixteenth century actually referred to the figure as a Constantine: the legend of Constantine the leper depicted at Riez in the Basses-Alpes, the painting of Constantine in the Baptistery at Poitiers. These two are authentic allusions, to my mind; the others, just such a case of the twelfth century misunderstanding antiquity as that of Aymery Picaud thinking that the lady caressing a lion, in the tympanum at Compostella, was a great lover fondling the skull of her dead paramour. The twelfth century made the same mistakes as we. As for Enlart's note that in the families of Melle and Surgères the name of Constantine occurs, all that ever it could prove is that babies were named in accordance with current tradition.

All these churches where the horseman is found lie on the road of returning pilgrims from Compostella. The pilgrimage antedates the carvings by many centuries. Since the horseman is indigenous to Spain, there is more likelihood that he was brought back thence than by the Roman pilgrims, for, as I have said, the figure is rare in the heart of Italy, and even St. George goes mostly afoot. In at least one instance a French church has copied Spain and partly misunderstood: at Vouvant (Vendée) on one side is the man tearing a lion of the Spanish churches and on the other a woman bending over what seems a dead baby. The dead baby was once a dead Moor, and the source was such a figure as the Santiago Matamoros at Sangüesa. Spain counts for much in the appearance of this twelfth-century motif, but there was probably beforehand something, a primitive stock on which to graft.

Along other pilgrimage-roads, through Auvergne, for example, the rider is not found. The soil was not congenial. Strabo recorded that the western Celts all worshipped the Dioscuri-there is a sarcophagus at Toulouse and an altar at Paris to confirm him. These horsemen tend to occur in pairs, as at Angoulême, and where there is only one the position is such as to call for some sort of pendant. Surgères, Parthenay, Sainte-Croix-de-Bordeaux, indeed, all of the churches sustain this observation. The great twin brethren who are the soldier saints have not been forgotten; they have only been christened. But the name bestowed in baptism varied: at Pontida it was James; at Bordeaux it was George, and so it was at Basel.

If the Dioscuri are the morning and evening stars, not seen together, we must expect to find the mortal twin left behind in folk-lore. So the rider, who is the tribal hero, comes at last to be the wild huntsman. Woden, the all-father, yet rides with his hell-hounds through the Hartz Mountains and the Black Forest. Theoderic of Verona rides straight to hell on the façade of S. Zeno (Fig. 12), but his galloping horse and his flying mantle are identical with those of Santiago Matamoros at La Coruña (Fig. 7) and the "Constantine" at Parthenay-le-Vieux (Fig. 13). Such a standing figure as that in Verona on the extreme right was observed by Mâle as an integral part of the French composition. So a plastic motive, like a religious motive, can live on with content completely varied. Finally, Arthur of Britain is also a wild huntsman in the north of England and in precisely that part of France where we find both the Celtic residue and the style of architecture in which the horseman is embedded. Arthur still rides in France in a broad strip along the west coast from Brittany to the Pyrenees, ${ }^{2}$ from the cape of Finisterre down to Cahors and Foix, and across the Pyrenees where Heine laid the scene of Atta Troll.

${ }^{1} L$ 'art du moyen age et les pèlerinages, Revue de Paris, October, 1912, pp. $717 \mathrm{ff}$. ; February, 1920, pp. $267 \mathrm{ff}$.

2Archer Taylor in the Romanic Review, 1921, II, pp. 286-289. In one English spell he is replaced by "St. George our Lady's knight," precisely as St. George replaces St. James at the siege of Huesca. 


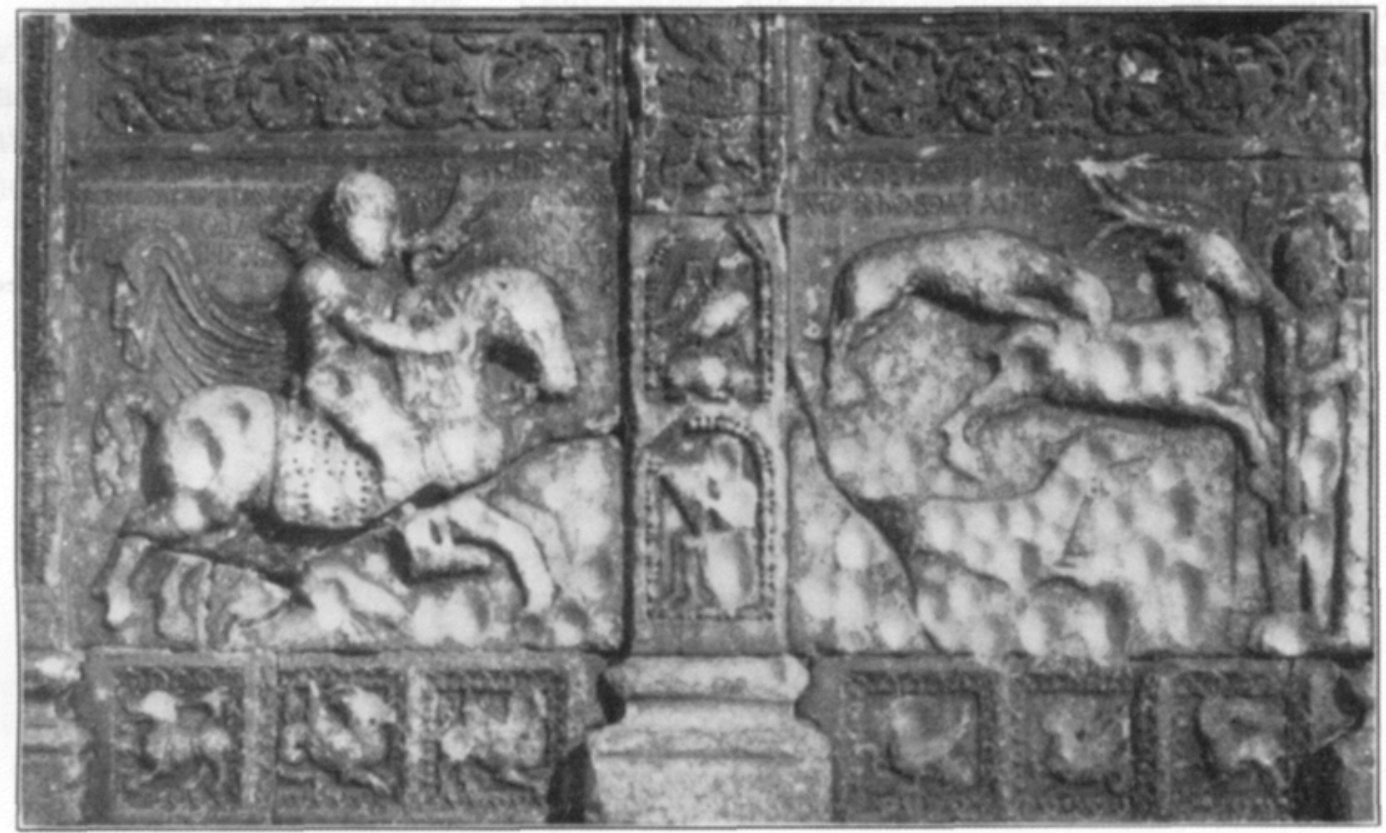

Fiti. 12- Verona, S. Zeno, Façade: Theodoric Riding to Hell, by Niccolò

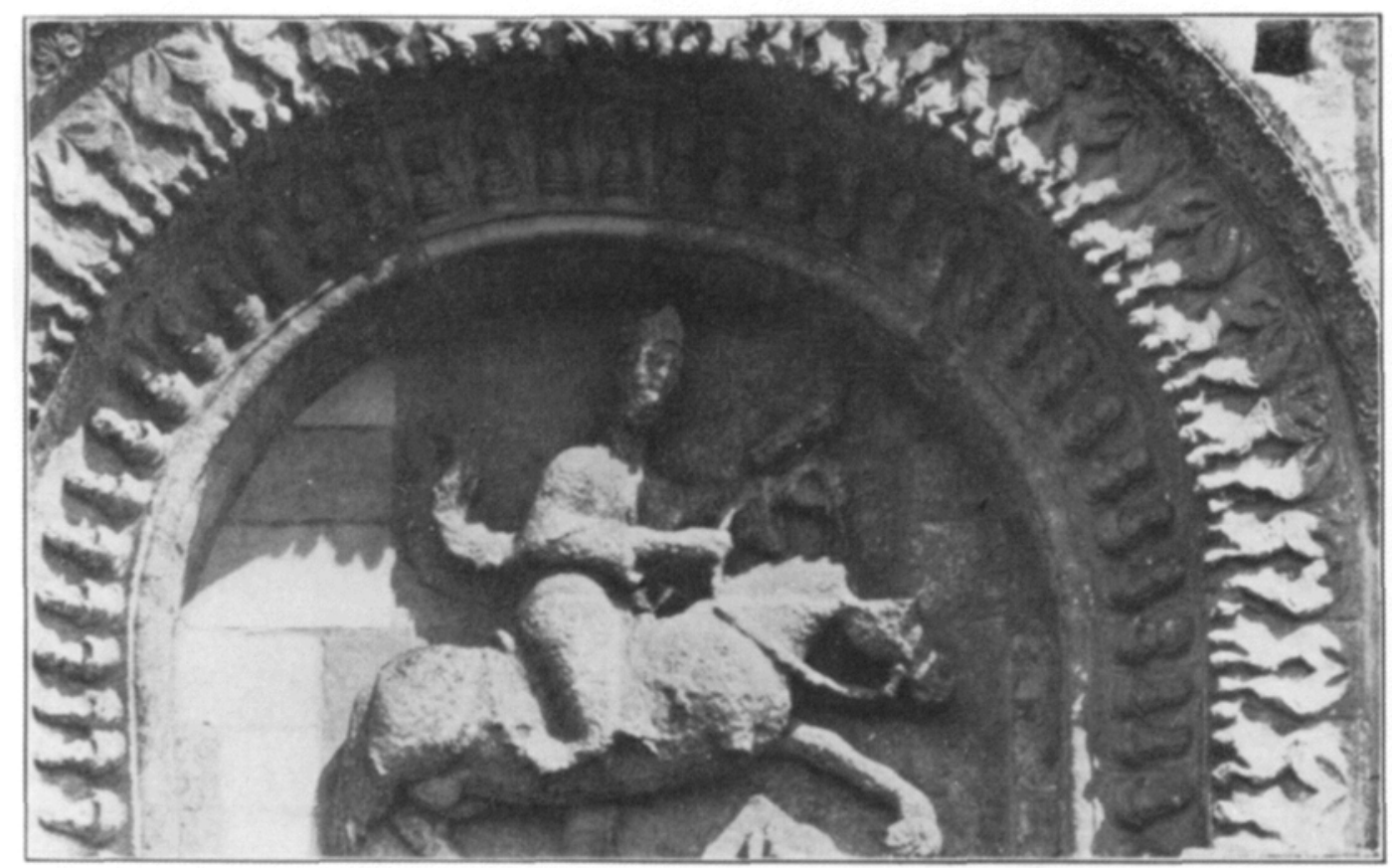

Fili. 13-Pakthesay-le-Vieux, Parish (hurch, Nukth Lunette of Façade: "Constantine" (Photo. Porter) 
Germanic the rider is not. I have shown his Mediterranean extension; in view of the evidence it seems likely that he was carried up to the rock-hewn relief that the Sassanians had carved by captive artisans, subjects of the empire, as he was carried up to the Swiss cathedral. Nowhere in Europe is the figure rooted so deeply as in Spain. ${ }^{1}$ It lives on in the art of Greco (Fig. 1) and in the novel of Blasco Ibañez.

The architecture of the French churches mentioned owes much to Spain and perhaps something directly to the East: whatever did not come from the Eastern Mediterranean regions came from Spain. 